\title{
EFFECT OF AQUATIC EXERCISE AFTER ECCENTRIC CONTRACTION-INDUCED MUSCLE INJURY
}

\section{EFEITO DO EXERCICIO AQUÁTICO DEPOIS DE LESÃO MUSCULAR PROVOCADA POR CONTRAÇÃO EXCÊNTRICA}

EFECTO DEL EJERCICIO ACUÁTICO DESPUÉS DE UNA LESIÓN MUSCULAR PORCONTRACCIÓN EXCÉNTRICA

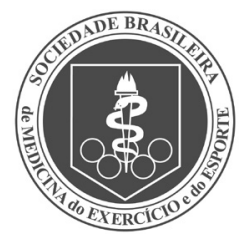

Original Article Artigo Original Artículo Original

\begin{abstract}
Daniel Boeira ${ }^{1,2}$ (D)
(Physical Education Professional)

Ramiro Doyernart 1,2 (ID)

(Physical Education Professional)

Fernanda Sombrio 1,2 (ID

(Physical Education Professional)

Julia Santos Medeiros ${ }^{1,2}$ (ID

(Physical Education Professional)

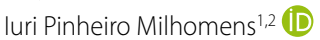

(Physical Education Professional)

Gabrielli Brina de Souza 1,2 (ID)

(Physical Education Professional)

Luciano Acordi da Silva ${ }^{1,2}$ (ID)

(Physical Education Professional)

1. Universidade do Extremo

Sul Catarinense (UNESC), Santa

Catarina, SC, Brazil.

2. Advanced Aquatic Exercise Research Group (GPEAA), Exercise Psychophysiology Laboratory (LaPsiCo - UNESC), Criciúma, SC, Brazil.
\end{abstract}

\section{Correspondence:}

Daniel Boeira

São Martinho 387, Bairro

Universitário, Criciúma - SC. Brazil. 88805-415.

danielboeira@unesc.net

\begin{abstract}
Introduction: Muscle microlesions produced by eccentric contractions (EC) cause changes in strength, endurance, power and neuromuscular activity parameters for an extended period of time. Objectives: To investigate the effect of aquatic exercise after EC-induced muscle injury on strength, endurance, power and neuromuscular activity parameters. Methods: A cross-sectional experimental study with six subjects (age $25 \pm 4$ years, weight 77 $\pm 4 \mathrm{~kg}$ and height of $162 \pm 2 \mathrm{~cm}$ ) with EC-induced muscle injury followed up during a recovery period (48h, $72 \mathrm{~h}$ and 96h) without intervention (Group 1A) and involving aquatic exercises (Group 1B). Dynamic and isometric strength, muscular endurance, and vertical/horizontal power tests as well as vastus lateralis neuromuscular activity measurements were performed before, immediately after, and during the recovery period. Results: Our results indicate that the intervention in Group 1B, when compared to Group 1A, accelerated the recovery of dynamic ( $p$ $<0.01)$ and isometric $(p<0.03)$ strength at $48 \mathrm{~h}$ and $72 \mathrm{~h}$, increased vertical power at $48 \mathrm{~h}(\mathrm{p}<0.05)$ and horizontal power at $48 \mathrm{~h}$ and $72 \mathrm{~h}(\mathrm{p}<0.05)$, and reduced neuromuscular activity $(\mathrm{p}<0.05)$ at $48 \mathrm{~h}$ and $72 \mathrm{~h}$ after EC. Conclusions: According to our findings, performing aquatic exercises during the recovery period improves muscle efficiency and accelerates strength, power and neuromuscular activity recovery. Level of evidence l; Randomized clinical trial.
\end{abstract}

Keywords: Eccentric exercise; Muscle damage; Active recovery.

\section{RESUMO}

Introdução: As microlesões musculares geradas por contrações excêntricas (CE) provocam alterações dos parâmetros deforça, resistência, potência e atividade neuromuscular por período prolongado. Objetivos: Investigar o efeito do exercício aquático depois de lesão muscular provocada por CE sobre os parâmetros força, resistência, potência e a tividade neuromuscular. Métodos: Estudo experimental cruzado com seis indivíduos (idade $25 \pm 4$ anos, peso $77 \pm 4 \mathrm{~kg}$ e altura $162 \pm 2$ $\mathrm{cm}$ ) com lesão muscular por CE e acompanhados durante um período de recuperação (48 h, $72 \mathrm{~h}$ e $96 \mathrm{~h}$ ) sem intervenção (Grupo 1A) eenvolvendo exercícios aquáticos (Grupo 1B). Antes, imediatamente edurante o período de recuperação foram realizados testes de força dinâmica, isométrica, resistência muscular, potência vertical/horizontal emensuração da atividade neuromuscular do músculo vasto lateral. Resultados: Nossos resultados apontam que a intervenção no Grupo 1B, em comparação com o Grupo 1A, acelerou a recuperação da força dinâmica $(p<0,01)$ e isométrica $(p<0,03)$ nos tempos de $48 \mathrm{~h}$ e $72 \mathrm{~h}$, aumentou a potência vertical no tempo de $48 \mathrm{~h}(p<0,05)$ e a horizontal nos tempos de $48 \mathrm{~h}$ e $72 \mathrm{~h}(p<0,05)$ e reduziu a atividade neuromuscular $(p<0,05)$ nos tempos de $48 \mathrm{~h}$ e $72 \mathrm{~h}$ depois de CE. Conclusões: De acordo com nossos achados, apontamos que os exercícios aquáticos durante o período de recuperação melhoram a eficiência muscular e aceleram a recuperação de força, potência e atividade neuromuscular. Nível de evidência l; Estudo clínico randomizado

Descritores: Exercício excêntrico; Recuperação ativa; Dano muscular.

\section{RESUMEN}

Introducción: Las microlesiones musculares generadas por contracciones excéntricas (CE) provocan alteraciones de los parámetros de fuerza, resistencia, potencia y actividad neuromuscular por período prolongado. Objetivos: Investigar el efecto del ejercicio acuático después de una lesión muscular provocada por CE sobre los parámetros fuerza, resistencia, potenciay actividad neuromuscular. Métodos: Estudio experimental cruzado con seis individuos (edad $25 \pm 4$ años, peso $77 \pm 4 \mathrm{~kg}$ y altura $162 \pm 2 \mathrm{~cm}$ ) con lesión muscular por CEy acompañados durante un período de recuperación (48h, 72h y 96h) sin intervención (Grupo 1A) e involucrando ejercicios acuáticos (Grupo 1B). Antes, inmediatamente después y durante el período de recuperación, fueron realizados tests de fuerza dinámica, isométrica, resistencia muscular, potencia vertical/horizontaly medición de la actividad neuromuscular del músculo vasto lateral. Resultados: Nuestros resultados apuntan que la intervención en el Grupo 1B, en comparación con el Grupo 1A, aceleró la recuperación de la fuerza dinámica $(p<0,01)$ e isométrica $(p<0,03)$ en 48 hy $72 h$, aumentó la potencia vertical en el tiempo de $48 \mathrm{~h}(p<0,05)$ y la horizontal en los tiempos de $48 \mathrm{~h}$ y $72 \mathrm{~h}(p<0,05)$ y redujo la actividad neuromuscular $(p<0,05)$ en los tiempos de $48 \mathrm{~h}$ y $72 \mathrm{~h}$ después de la CE. Conclusiones: De acuerdo con nuestros hallazgos, apuntamos que los ejercicios acuáticos durante el período de recuperación mejoran la eficiencia musculary aceleran la recuperación de fuerza, potencia y actividad neuromuscular. Nivel de evidencia l; Estudio ensayo clínico aleatorizado.

Descriptores: Ejercicio excéntrico; Daño muscular; Recuperación activa. 


\section{INTRODUCTION}

Muscle microlesions caused by eccentric contractions (EC) involve a sequence of events. Initially, mechanical factors (contraction and stretching) produce sarcomere rupture, impairment of actin/myosin coupling and calcium signaling, and degradation of the sensory receptors that are metabolically involved. ${ }^{1,2}$

Previous studies carried out in our laboratory ${ }^{2,3}$ suggest that ECs cause microlesions, thereby changing parameters of strength, performance, inflammation, and oxidative stress for an extended period. This represents cause for concern in the world of sports, since the recovery time between one sport activity and another can be extremely short. ${ }^{4}$

Specifically regarding muscle injuries in sportspeople, Guermazi et al. ${ }^{5}$ analyzed their occurrence in the Rio de Janeiro Olympics and noticed that the highest incidence occurred in athletics and soccer, with $89 \%$ of these affecting lower limbs, mainly in the thigh muscle groups.

To this end, strategies aimed at accelerating muscle recovery after EC to improve performance have been the subject of some studies. ${ }^{2,3,6,7}$ Studies suggest that low-intensity physical exercises can assist in the muscle recovery process. ${ }^{8,9}$ From this perspective, Aquatic Exercises (AE) have been used for muscle recovery, due to the physical properties of water (hydrostatic pressure and buoyancy), and consequently their physiological and biochemical effects. ${ }^{7,8}$

However, little is known about the effect of $A E$, during the recovery period, on strength, endurance, power and neuromuscular activity parameters in subjects who have sustained EC-induced lower limb muscle injuries. Thus, the purpose of this study was to investigate the effect of aquatic physical exercise after eccentric contractions on strength, endurance, power, and neuromuscular activity parameters.

\section{MATERIALS AND METHODS}

Ethical documents: This study was conducted in accordance with Brazilian National Board of Health Resolution no. 466/12, and approved by the local Institutional Review Board of Universidade do Extremo Sul Catarinense (opinion no. 77971317.7.0000.0119). All participants signed the Informed Consent Form (ICF) before participating in the study.

This is a crossover randomized controlled clinical trial carried out in the following time sequence: Intervention (1A); tests + eccentric contraction + tests. A 14-day interval was followed by intervention (1B); tests + eccentric contraction + aquatic intervention + tests (Figure 1). The participants underwent a total of 10 identical assessments, which were divided into two time points ( $1 A$ and $1 B)$. The data from the first five assessments correspond to intervention $A(1 A)$, and the subsequent five assessments correspond to intervention $B(1 B)$. After performing the tests and the EC protocol in intervention 1A, the subjects did not undertake any recovery strategy, only absolute rest. However, in intervention $1 \mathrm{~B}$, all subjects performed the aquatic exercises 24 hours after the eccentric contractions.

Six male non-athletes (age $25 \pm 4$ years, weight $77 \pm 4 \mathrm{~kg}$, and height $162 \pm 2 \mathrm{~cm}$ ), students at a higher education institution in Santa Catarina, Brazil, participated in the study. Subjects who agreed not to take a nutritional supplement, and not to perform strength training or any type of exercise that could compromise the results of the research during the interventions, were included in the experiment. Exclusion criteria were as follows: Tobacco use, history of recent muscle injury or subjects with a disease that could compromise the results of the research or be aggravated by participation in physical exercise, diagnosed during the previous six months.

We used the EC protocol adapted from Silva et al. ${ }^{3}$ in which the participants performed three sets of maximal eccentric contractions lasting six to eight seconds, performing the knee flexion movement in the leg

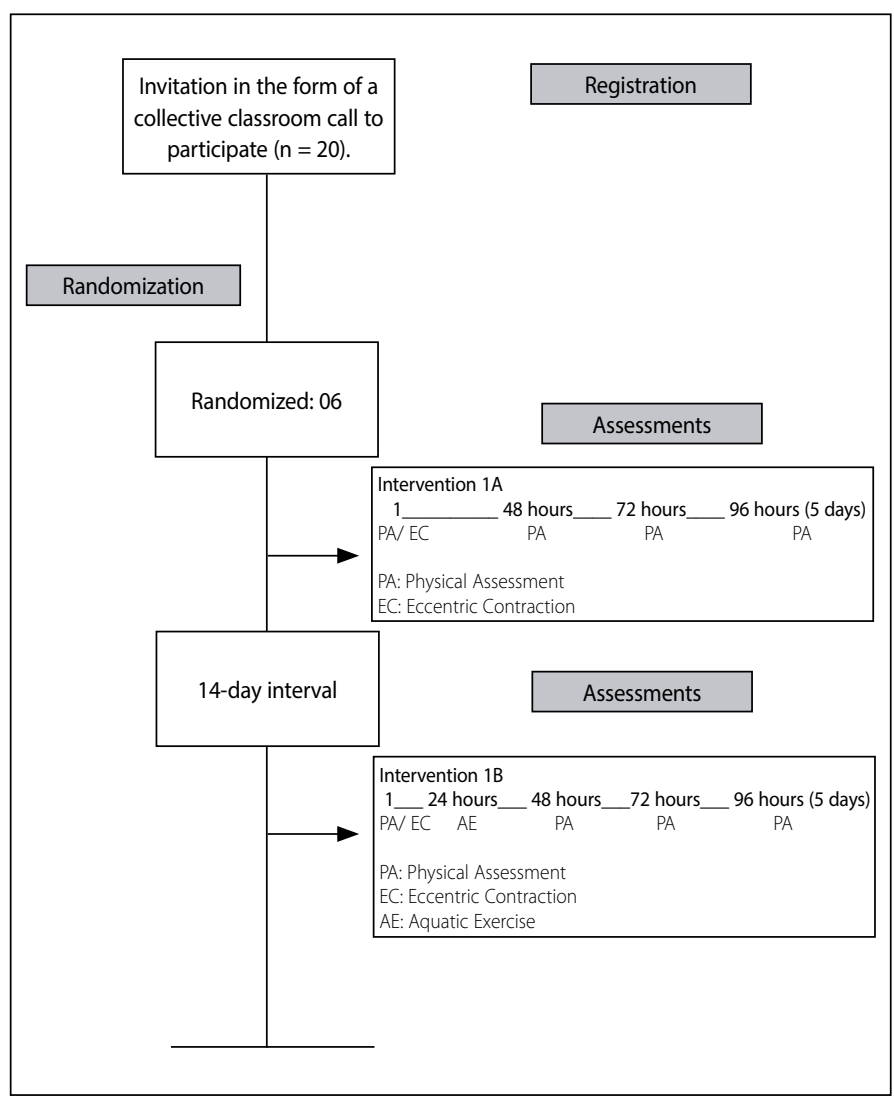

Figure 1. Flow diagram showing the participant registration, allocation, follow-up and analysis process.

extension machine. The concentric phase of movement (extension) was carried out by the researchers. The protocol was considered finalized as soon as the participant was unable to maintain EC for a minimum period of 6 seconds, or due to the participant's withdrawal.

The AE session was held over 30 minutes, divided into five minutes of warm-up exercises, 20 minutes of exercises, and five minutes of relaxation and stretching. Aerobic exercises (running, shuffles, and combined arm and leg movements) were performed according to the guidelines of the professional manual on aquatic physical exercises..$^{10}$ As an exercise intensity control variable, we used the Subjective Effort Perception (SEP) scale, adapted from 0 to 10 points, as it is an instrument frequently used in clinical studies. ${ }^{11,12}$ All subjects were instructed to perform the exercises at a low level of exertion (4 to 6 points on the SEP scale), where intensity was selected by the participants themselves.

Lower limb power was measured using the Vertical Jump (VJ) and Horizontal Jump (HJ) tests. ${ }^{13}$ Dynamic muscle strength was measured using the one-repetition maximum (1RM) test. ${ }^{14}$ Maximum voluntary isometric contraction (MVIC) was adapted from Hermens et al., ${ }^{15}$ in which the volunteers maintained isometric contraction at 90\% of 1RM at an angle of $140^{\circ}$, which was determined by means of a goniometer (Carci, São Paulo, Brazil), positioned between the condyles. Localized Muscular Resistance (LMR) was measured using the resistance strength test, ${ }^{16}$ in which the volunteers performed as many repetitions as possible at 50\% of 1RM.

The neuromuscular activity of the vastus lateralis was measured during the dynamic strength, MVIC and LMR tests using a surface electromyograph (EMG) model EMG 800-C (produced by EMG System do Brasil Ltda), employing the root mean square (RMS) to determine the value. The signal captured by the electrodes was amplified 2000 times and filtered with bandpass filters at a frequency of 20 to $500 \mathrm{~Hz}$ with common mode rejection $>120 \mathrm{~dB}$. Electrical activity was captured by means of active bipolar surface adhesive electrodes, with 20x gain pre-amplification, shielded cable and pressure clip at the ends of the 
electrodes. The electrodes were attached to the vastus lateralis muscle (VLM) of the dominant leg after local asepsis and trichotomy following the recommendations of the Surface ElectroMyoGraphy for the Non-Invasive Assessment of Muscles (SENIAM) project.

\section{Statistical analysis}

All the data were analyzed using the standard procedure (mean \pm mean standard deviation). The distribution of normality was verified using the Shapiro-Wilk test after the Student's t test was applied to the dependent samples, adopting a level of significance established for the statistical test of $\mathrm{p}<0.05$, using SPSS (Statistical Package for Social Sciences) version 20.0.

\section{RESULTS}

\section{Dynamic strength}

According to (Figure 2), there was a significant reduction of $50 \%$ in both interventions immediately after EC in strength levels. However, $1 \mathrm{~B}$ returned to baseline levels of dynamic strength at $48 \mathrm{~h}$ and $72 \mathrm{~h}$, while intervention $1 \mathrm{~A}$ only achieved baseline levels at $96 \mathrm{~h}$. In percentage terms, this recovery of dynamic strength was 50\% faster in intervention 1B.

\section{Isometric strength}

An increase was observed in MVIC in intervention 1B (Figure 3) during the recovery period at the $48 \mathrm{~h}(38.92 \pm 3 \mathrm{~s} ; 93.3 \%)$ and $72 \mathrm{~h}(40.75 \pm 3.4 \mathrm{~s}$; $101.8 \%)$ time intervals when compared to group $1 \mathrm{~A}(25.6 \pm 4.5 ; 33.7 \pm$ $3.7 \mathrm{~s})$, respectively. In percentage terms, this recovery of strength was 25\% faster in intervention $1 \mathrm{~B}$.

\section{Localized muscular resistance}

According to (Figure 4), there was a significant reduction in the number of repetitions (rep) in both interventions during the recovery period (values 1B; 1A), 48h (14 \pm 1.0 rep; $17.66 \pm 1.2$ rep), $72 \mathrm{~h}$ (14.66 \pm 2.3 rep; $16.5 \pm 1.7$ rep), when compared to pre-exercise (20.27 \pm 2.4 rep; $20.2 \pm 2.2$ rep), respectively with no difference between them ( $p>0.05$ ).

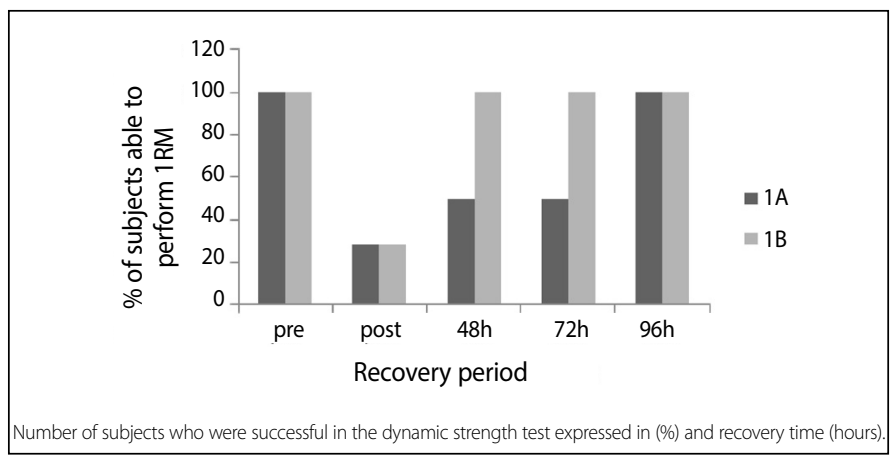

Figure 2. Dynamic strength.

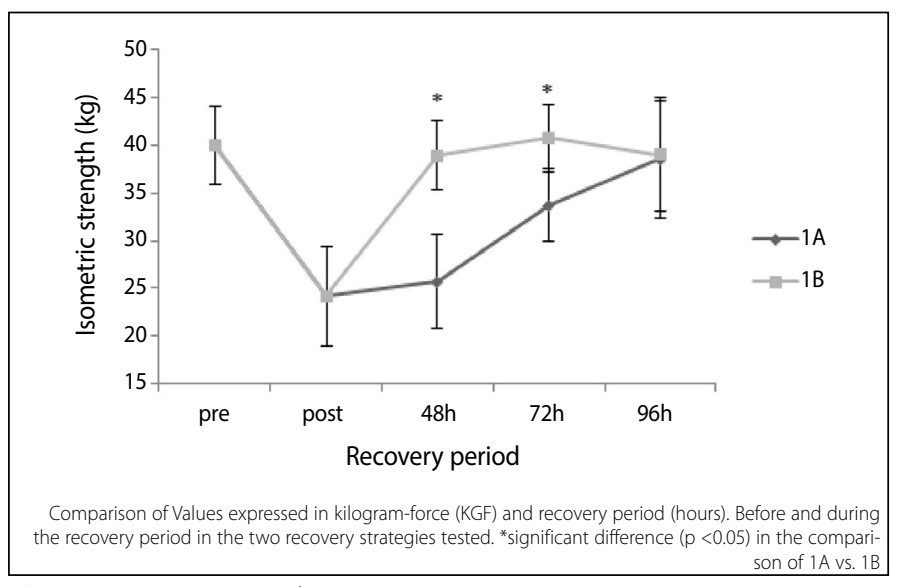

Figure 3. Isometric strength.

\section{Vertical power}

According to the values found in (Figure 5), intervention 1B achieved a faster recovery $(p<0.05)$ in the $V J$ (vertical jump) at $48 \mathrm{~h}(47 \pm 1.3 \mathrm{~cm})$ when compared to intervention $1 \mathrm{~A}(43.4 \pm 1.8 \mathrm{~cm})$. In percentage terms, this recovery was $50 \%$ faster.

\section{Horizontal power}

The results (Figure 6) show a faster recovery $(p<0.05)$ in $\mathrm{HJ}$ (horizontal jump) in intervention $1 \mathrm{~B}$ at $48 \mathrm{~h}(193.9 \pm 5.8 \mathrm{~cm} ; 97.7 \%)$ and $72 \mathrm{~h}$ $(195.2 \pm 4.2 \mathrm{~cm} ; 98.4 \%)$ when compared to $1 \mathrm{~A}(188.8 \pm 9.3 \mathrm{~cm})$ and $(182.3 \pm 7.3$ $\mathrm{cm}$ ) respectively. In percentage terms, this recovery in power was $50 \%$ faster.

Regarding dynamic strength, our results (Table 1) indicate lower post-aquatic intervention activity (1B) at 48h (960.7 $\pm 245.4 \mathrm{rms} ; 56.7 \%)$ and $72 \mathrm{~h}(911.9 \pm 190.4 \mathrm{rms} ; 53.8 \%)$ when compared to $1 \mathrm{~A}(1371.6 \pm$ 141.3 rms; 64.2\%; $1477.2 \pm 134.3$ rms; $84.3 \%$ ) respectively. Regarding IS, our results indicate lower activity levels in $1 \mathrm{~B}$ at $48 \mathrm{~h}$ (164.4 $\pm 25.1 \mathrm{rms}$; $60.7 \%)$ and $72 \mathrm{~h}(175.6 \pm 17.4 ; 64.9 \%)$ when compared to $1 \mathrm{~A}(238.1 \pm$ $24.2 \mathrm{rms} ; 227.2 \pm 13.4 \mathrm{rms}$ ), respectively. Regarding muscular endurance, our results indicate lower activity levels in $1 \mathrm{~B}$ at $48 \mathrm{~h}$ (199.6 $\pm 13.4 \mathrm{rms}$ ) and $72 \mathrm{~h}(204.5 \pm 16 ., \mathrm{rms})$ when compared to $1 \mathrm{~A}(216.6 \pm 17.4 \mathrm{rms} ; 223.4 \pm$ 13.7 rms), respectively.

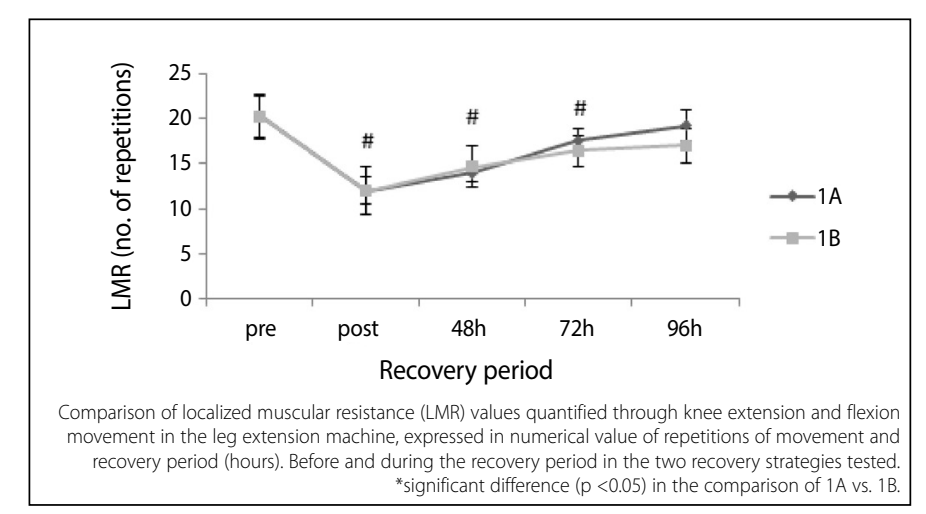

Figure 4. Localized muscular resistance.

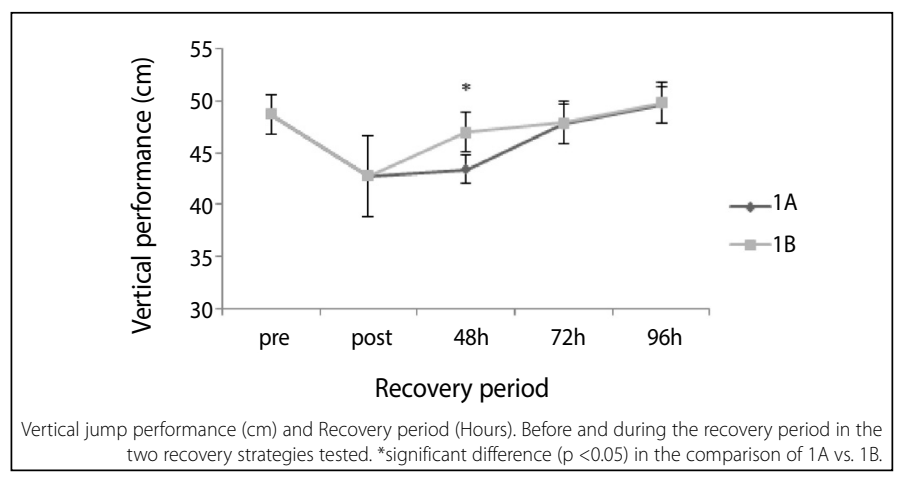

Figure 5. Vertical power.

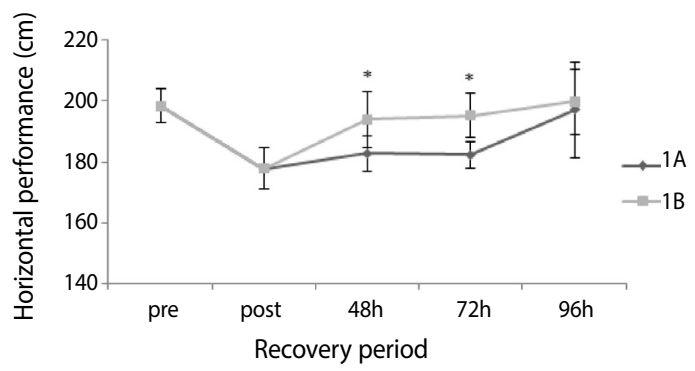

Horizontal jump performance $(\mathrm{cm})$ and Recovery period (Hours). Before and during the recovery period in the two recovery strategies tested. *Significant difference $(p<0.05)$ in the comparison of 1A vs. 1B.

Figure 6. Horizontal power. 
Table 1. Anthropometric characteristics.

\begin{tabular}{c|c}
\hline & Values \\
\hline Age & $25 \pm 4.49$ \\
\hline Weight & $77 \pm 4$ \\
\hline Height & $162 \pm 23$ \\
\hline Supplements & 0.0 \\
\hline
\end{tabular}

Age (years); Weight (kg); Height (cm) and Supplements (no.).

\section{DISCUSSION}

This study indicated that AEs of low intensity and moderate volume significantly accelerate the muscle recovery process after EC, improving muscle strength and power parameters. We found that in relation to neuromuscular activity, there was less activation of the vastus lateralis muscle after recovery followed by $A E$ in all three parameters (dynamic/isometric strength and muscular endurance), indicating better muscle efficiency.

Microlesions caused by EC bring about a decrease in the capacity to generate force and muscle performance., ${ }^{2,6,7}$ In Figure 2 we can see that in both interventions, ECs reduced dynamic strength immediately afterwards, confirming the effectiveness of the model for lower limbs. We should point out that intervention (1B) involving AE promoted a faster recovery of dynamic strength levels during the recovery period (48h and 72h), when compared to the intervention without AE. Maruyama et al. ${ }^{17}$ found no improvements using a combination of cold water immersion and compression garments. However, Legault et al. ${ }^{18}$ found improvements in recovery from EC-induced muscle injuries, using L-Glutamine intake. A possible physiological explanation for our findings is related to the increase in local blood flow caused by the decrease in Ph produced by $A E$, thus allowing a greater exchange of nutrients and removal of metabolites, immediately after EC. ${ }^{19,20}$

As a second parameter of muscle function, we assessed IS, which was defined as muscle action that produces force without changes in the joint angle. ${ }^{19}$ Our results, according to (Figure 3 ), indicate a greater force production capacity after intervention $1 \mathrm{~B}$ during the recovery period (48h, 72h), when compared to $1 \mathrm{~A}$. These results are consistent with the findings of Reilly et al., ${ }^{21}$ who observed an improvement in isometric strength levels in adults who had undergone water running after plyometric exercises. Studies such as those carried out by Apostolopoulos et al., ${ }^{22}$ who used three different passive stretching intensities, did not find a significant improvement in isometric strength parameters after EC. It is believed that this improvement can be explained by the association of forces such as: hydrostatic pressure and buoyancy, which contribute to a more efficient venous return, via the transfer of extracellular fluid to the intravascular compartment and subsequent increase in cardiac output, thus being able to accelerate the removal of metabolites accumulated during microlesions caused by EC. 20,23

Regarding LMR, this has been characterized as the ability of a muscle to resist fatigue under conditions of prolonged strength performance. ${ }^{19}$ Studies have shown contradictory results for the improvement of LMR after strategic recovery interventions., ${ }^{2,17}$ Our results (Figure 4), corroborate a loss of LMR, both in intervention $1 \mathrm{~A}$ and $1 \mathrm{~B}$. According to Hicks et al., ${ }^{24}$ recovery of muscular functional capacity after muscle injury can take up to ten days, which could explain the non-recovery of LMR.

As regards muscle power, our results (Figures 5 and 6) indicate greater horizontal and vertical power after intervention $1 \mathrm{~B}$ at $48 \mathrm{~h}$ for the $\mathrm{VJ}$ and 48 and $72 \mathrm{~h}$ for the $\mathrm{HJ}$, when compared to $1 \mathrm{~A}$. It is believed that AEs performed during recovery help restore homeostatic balance, bringing the musculoskeletal muscle close to baseline levels of power production and maintenance at an early stage. According to Mekjavick et al., ${ }^{25}$ immersion in the liquid medium triggers blood redistribution, with an increase in venous return and consequently in cardiac output, which would produce an increase in the volume of oxygen consumed
$\left(\mathrm{VO}_{2}\right)$, leading to greater autotransfusion in the capillaries. In physical terms, this can be explained by hydrostatic pressure, which would aid in the venous and lymphatic return flow, causing the blood flow to migrate from the peripheral to the central region, and consequently triggering the activation of defense cells, thereby accelerating the recovery process. ${ }^{7,26}$

Another possible explanation is that AEs would entail a greater flow of oxygenated blood to the regions exposed to muscle damage, facilitating the supply of metabolic agents. This factor has been pinpointed as a predictor of the recovery of homeostatic levels of intramuscular $\mathrm{Ca}+{ }^{19-21}$ acting as a physiological aid in muscle rebalancing and restoration.

Finally, we analyzed muscle electromyography activity during the dynamic/isometric strength and LMR tests during the recovery period. The purpose of electromyography activation is to measure the action potentials activated during muscle contractions, serving as an indicator of muscle efficiency. ${ }^{27}$ In injured muscles, physiology has described an inability to maintain $\mathrm{Na}+$ and $\mathrm{K}+$ concentrations, which results in changes in the reception of $\mathrm{Ca}+$ ions and consequently muscle inefficiency in the generation of strength and resistance. ${ }^{19}$ This mechanism leads to a failure in the interaction of the cross bridges (actin/myosin), producing a greater propagation of the electrical impulse, without generating performance. ${ }^{27}$ Our results (Table 2 ) show that in the three parameters evaluated, intervention 1B achieved less muscle activity at $48 \mathrm{~h}$ and $72 \mathrm{~h}$, generating greater performance (Figures 5,6) when compared to intervention $1 \mathrm{~A}$. According to Bonato et al., ${ }^{28} \mathrm{Knaflitz}$ and Bonato, ${ }^{29}$ this result indicates, in physiological terms, that the muscle has recovered better from ECs, and has thus achieved greater muscle efficiency, requiring less action potential to depolarize and consequently produce force. In this regard, Macgregor and Hunter ${ }^{30}$ found positive changes between motor unit activity and strength recovery following muscle damage.

Table 2. Electromyography activity.

\begin{tabular}{|c|c|c|c|c|c|c|}
\hline & & Pre & Post & $48 \mathrm{~h}$ & $72 \mathrm{~h}$ & $96 \mathrm{~h}$ \\
\hline \multirow{4}{*}{$\begin{array}{l}\text { Dynamic } \\
\text { strength }\end{array}$} & \multirow{2}{*}{$1 \mathrm{~A}$} & 1695.43 & 1411.95 & 1371.66 & 1477.27 & 1229.82 \\
\hline & & \pm 245.65 & \pm 186.62 & \pm 141.33 & \pm 134.39 & \pm 167.29 \\
\hline & \multirow{2}{*}{$1 \mathrm{~B}$} & $x$ & $x$ & $960.79^{*}$ & $911.95^{*}$ & 1181.79 \\
\hline & & $x$ & $x$ & \pm 245.48 & \pm 190.40 & \pm 175.78 \\
\hline \multirow{4}{*}{$\begin{array}{l}\text { Isometric } \\
\text { strength }\end{array}$} & \multirow{2}{*}{$1 \mathrm{~A}$} & 270.76 & 306.94 & 238.13 & 227.29 & 238.66 \\
\hline & & \pm 22.23 & \pm 47.21 & \pm 24.23 & \pm 13.42 & \pm 40.06 \\
\hline & \multirow{2}{*}{$1 \mathrm{~B}$} & $x$ & $x$ & $164.43^{*}$ & $175.67^{*}$ & 188.21 \\
\hline & & $x$ & $x$ & \pm 25.17 & \pm 17.43 & \pm 48.58 \\
\hline \multirow{4}{*}{$\begin{array}{l}\text { Muscular } \\
\text { resistance }\end{array}$} & \multirow{2}{*}{$1 \mathrm{~A}$} & 277.16 & 270.38 & 216.68 & 223.48 & 221.81 \\
\hline & & \pm 26.49 & \pm 9.21 & \pm 17.42 & \pm 13.75 & \pm 12.53 \\
\hline & \multirow{2}{*}{$1 \mathrm{~B}$} & $x$ & $x$ & $199.65^{*}$ & $204.54^{*}$ & 213.91 \\
\hline & & $x$ & $x$ & \pm 13.45 & \pm 16.54 & \pm 13.83 \\
\hline
\end{tabular}

Electromyography activity of the Vastus lateralis muscle of the dominant limb, in the IS, DS and LMR tests expressed in root mean square (RMS). Before and during the recovery period in the two recovery strategies tested. ${ }^{*}$ significant difference $(p<0.05)$ in the comparison of 1 A vs. $1 B$.

\section{CONCLUSIONS}

According to our findings, it is possible to conclude that a low intensity (4-6 SEP) and moderate volume (30 min) aquatic exercise session improves dynamic/isometric strength and LMR parameters of lower limbs in men. It should be noted that AEs physiologically reduce neuromuscular activity of the vastus lateralis during the recovery period, after EC, serving as an indicator of muscle efficiency. Study limitations are 
the non-measurement of $\mathrm{VO}_{2}$ max and the biochemical quantification (oxidative stress and inflammation) of the recovery process.
Nacional de Desenvolvimento Científico e Tecnológico [National Council for Scientific and Technological Development] (CNPq/CAPES).

\section{ACKNOWLEDGMENT}

Universidade do Extremo Sul Catarinense (UNESC); Conselho

All authors declare no potential conflict of interest related to this article

AUTHORS' CONTRIBUTIONS: Each author made significant individual contributions to this manuscript. DB: formal analysis, methodology, writing and preliminary text; ISM: statistical analysis, surgeries and review; RD: concept, methodology, supervision; IPM: methodology, validation; FS: formal analysis, methodology, validation; GBS: formal analysis, investigation, supervision; LAS: conceptualization, review and editing, data curation, software. All authors read and approved the final version of the article.

\section{REFERENCES}

1. Fu C, Xia Y, Meng F, Li F, Liu Q, Zhao H, et al. MRI Quantitative Analysis of Eccentric Exercise-induced Skeletal Muscle Injury in Rats. Acad Radiol. 2020;27(4):e72-9.

2. Silva LA, Tromm CB, Da Rosa G, Bom K, Luciano TF, Tuon T, et al. Creatine supplementation does not decrease oxidative stress and inflammation in skeletal muscle after eccentric exercise. J Sports Sci. 2013;31(11):1164-76.

3. Silva LA, Pinho CA, Silveira PC, Tuon T, De Souza CT, Dal-Pizzol F, Pinho RA. Vitamin E supplementation decreases muscular and oxidative damage but not inflammatory response induced by eccentric contraction. J Physiol Sci. 2010;60(1):51-7.

4. Peltier SL, Leprêtre PM, Metz L, Ennequin G, Aubineau N, Lescuyer JF, et al. BrinkT, Sirvente P. Effects of pre-exercise, endurance, and recovery designer sports drinks on performance during tennis tournament simulation. J Strength Cond Res. 2013;27(11):3076-83.

5. Guermazi A, Hayashi D, Jarraya M, Crema DM, Bahr R, Roemer FW, et al. Sports injuries at the Rio de Janeiro 2016 Summer Olympics: use of diagnostic imaging services. Radiology. 2018;287(3):922-32.

6. Abaidia AE, Lamblin J, Delecroix B, Leduc C, Mccall A, Nédélec M, et al. Recovery From Exerciseinduced Muscle Damage: Cold-Water Immersion Versus Whole-Body Cryotherapy. Int J Sports Physiol Perform. 2017;12(3): 402-9.

7. Malta ES, Lira FS, Machado FA, Zago AS, Amaral SL, Zagatto AM. Photobiomodulation by led does not alter muscle recovery indicator na presentes similar outcomes to cold-water immersion and active recovery. Front Physiol. 2019;9:1948.

8. Torres R, Ribeiro F, Duarte JA, Cabri JM. Evidence of the physiotherapeutic interventions used currently after exercise-induced muscle damage: Systematic review and meta-analysis. Phys Ther Sport. 2012;13(2):101-14.

9. Peak JM, Roberts LA, Figueiredo VC, Egner I, Krog S, Aas SN, et al. The effects of cold water immersion and active recovery on inflammation and cell stress responses in human skeletal muscle after resistence exercise. J Physiol. 2017;595(3):695-711.

10. Aquatic Exercise Association. Fitness aquático: um quia completo para profissionais. 6. ed. Barueri, SP: Manole; 2014.

11. Silva LA, Tortelli L, Motta J, Menguer L, Mariano S, Tasca G, et al. Effects of aquatic exercise on mental health, functional autonomy ad oxidative stress in depressed elderly individual: a randomized clinica trial. Clinics. 2019;74:e322.

12. Compagnat M, Salle JY, Mandigout S, Lacroix J, Vuillerme N, Daviet JC. Rating of perceived exertion with Borg scale in stroke over two common activites of the daily living. Top Stroke Rehabil. 2018;25(2):145-9.

13. Johnson BL, Nelson JK. Practical measurements for evaluation in physical education. 1. ed. Minnesota: Burgess Publishing Company. 1969.

14. Bompa TO, Haff G. Periodização: teoria e metodologia do treinamento. 5. ed. São Paulo: Phorte; 2012.
15. Hermens HJ, Freriks B, Merletti R, Stegeman D, Blok J, Rau G, et al. European recommendations for surface electromyography. SENIAM. 1999;8:55-79.

16. Azevedo PH, Demampra TH, Oliveira GP, Baldissera V, Mendonça MB, Marques AT, et al. Efeito de 4 semanas de treinamento resistido de alta intensidade e baixo volume na força máxima, endurance muscular e composição corporal de mulheres moderamente treinadas. Braz J Biomot. 2007;1 (3):76-85.

17. Maruyama T, Mizuno S, Goto K. Effects of cold water immersion and compression garmet use after eccentric exercise on recovery. J Exerc Nutrition Biochem. 2019;23(1):48-54.

18. Legault Z, Bagnall N, Kimmerly DS. The influence of oral L- Glutamine supplementation on muscle strength recovery and sroness following unilateral knee extension eccentrix exercise. Int J Sport Nutr Exerc Metab. 2015;25(5):417-26.

19. Hall JE. Guyton \& Hall: fundamentos de fisiologia. 12. Ed. Rio de Janeiro: Elsevier; 2012.

20. Abbas AK, Lichtman AH, Pillai S. Imunologia celular e molecular. Rio de Janeiro: Elsevier; 2015.

21. Reilly T, Ekblom B. The use of recovery methods post-exercise. J Sports Sci. 2005; 23(6): 619-27.

22.Apostolopous NC, Lahart IM, Plyley MJ, Taunton J, Nevill AM, Koutedakis Y, et al. The effects of diferente passive static stretching intensities on recovery from unaccustomed eccentric exercise $-\mathrm{A}$ randomized crontolled trial. Applied physiology. Appl Physiol Nutr Metab. 2018;43(8):806-15.

23. Lucertini F, Gervasi M, D'amen G, Sisti D, Rocchi MB, Stochi V, et al. Effect of water-based recovery on blood lactate removal after high-intesity exercise. Plos One. 2017;12(9):e184240.

24. Hicks KM, Onambele GL, Winwood K, Morse Cl. Muscle damage following maximal eccentric knee extensions in males and females. PLoS One. 2016;11 (3):e015848.

25. Mekjavick IB, Bligh J. The increased oxygen uptake upon immersion. The raised external pressure could be a causative factor. Eur J Appl Physiol Occup physiol. 1989;58(5):556-62.

26. Pendergast DR, Moon RE, Kraney JJ, Held HE, Zamparo P. Human physiology in an aquatic environmente. Compr Physiol. 2015;5(4):1705-50.

27. Bazzucchi I, Patrizio F, Ceci R, Duranti G, Sgro P, Sabatini S, et al. The effects of quercetin supplementation on eccentric exercise-induced muscle damage. Nutrients. 2019;11(1):205-21.

28. Bonato P, Roy SH, Knaflitz M, De Luca CJ. Time-frequency parameters of the surface mioelectric signal for assessing muscle fatigue during cyclic dybamic contractions. IEEE Trans Biomed Eng. 2001;48(7):745-53.

29. Knaflitz M, Bonato P. Time-frequency methods applied to muscle fatigue assessment during dynamic contactions. J Electromyogr Kinesiol. 1999;9(5): 337-50.

30. Macgregor LJ, Hunter AM. High-threashold motor unit firing reflects force recovery following a bout of damaging eccentric exercise. Plos One. 2018;13(4):e019051. 